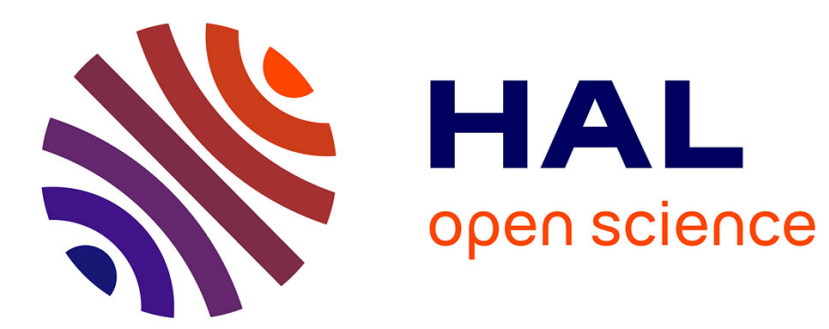

\title{
Popularization of science as the autobiography of science
}

Baudouin Jurdant

\section{To cite this version:}

Baudouin Jurdant. Popularization of science as the autobiography of science. Public Understanding of Science, 1993. hal-01744972

\section{HAL Id: hal-01744972 \\ https://hal.science/hal-01744972}

Submitted on 27 Mar 2018

HAL is a multi-disciplinary open access archive for the deposit and dissemination of scientific research documents, whether they are published or not. The documents may come from teaching and research institutions in France or abroad, or from public or private research centers.
L'archive ouverte pluridisciplinaire HAL, est destinée au dépôt et à la diffusion de documents scientifiques de niveau recherche, publiés ou non, émanant des établissements d'enseignement et de recherche français ou étrangers, des laboratoires publics ou privés. 


\title{
Popularization of science as the autobiography of science
}

\author{
Baudouin Jurdant
}

\begin{abstract}
In this paper I investigate the status of popular science texts as a literary genre and ask how a text can be recognized as belonging to that genre. To determine this I compare popular science texts with science fiction, which indicates that it is popular science's truth claims which give the literary genre of popular science its place in literature as a whole. However, critics have argued that literature is not concerned with truth which implies that popular science texts - despite being written documents - are not literature. To resolve this I compare popular science with autobiography - another genre which makes truth claims - and examine the products of their shared intention of telling the truth about the natural world in the case of popular science, and about 'oneself' in the case of autobiography.
\end{abstract}

The term 'popularization of science' refers mainly to written texts. This does not mean that other media are not used for transmitting scientific knowledge to an audience wider than the restricted community of experts and specialists. Instead, a 'diversity of forms for the same content' is advisable if we are to believe that science, because it deals with reality, is just the same for all. But rather than science, it is reality which is believed to be the same for all. Science is not. The science of the specialist does not look like the science of the layperson. But, as we all know, since science is not concerned with appearances, we are left with the idea that the science is actually the same, behind these appearances which make it look different for different people.

There are some advantages to looking at popularization of science in its textual forms. It allows us to ignore the educational intentions which are embedded in the messages of popularisers and to stick to their literary form for its own sake. Without this background of intent, we can no longer rely on the tacit complicity which relates, beyond the text, a writer to its reader. The text must speak for itself. The question that we can then ask is this : if all texts belong to some kind of literary genre, obeying specific rules which enable people to recognize the kind of text they are reading, then popularization of science must be considered as a genre littéraire, the rules of which can be formulated explicitly. Of course, I do not intend to identify such rules according to the didactic intentions of the 
authors when elaborating their messages. Various authors have already done this, giving prescriptions to science writers which will allow large audiences to understand their messages. Recently in France, for example, Pierre Laszlo, a chemist, published a little book on 'popularization of science'1, where the apprentice popularizer is invited to discover the rules of their art : they are advised to write in plain language, not using too much scientific jargon; to [365] construct short sentences, if possible, without too many subordinate clauses; to provide illustrations and preferably drawings; to start with very short summaries; and so on. The average sentence length should not exceed 22 words and the average length of the words should be less than six letters. This advice is indeed welcome, and one cannot but agree that it appears to be necessary to repeat such instructions to science writers, especially since they do not appear to be particularly keen on following them. So I won't invite you to listen again to educational prescriptions. I shall look at the text itself, as it stands before the eyes of the reader, without referring it to the didactic intention of its author.

\section{Popularization of science versus science fiction}

How shall we elicit the rules of the genre? The first thing one can do is to compare popular presentations of science with other kinds of literary pieces which have some science content. Science fiction seems to be the nearest literary form to popularization of science. And indeed, if you take some passages of Jules Verne and compare them with similar passages from Félix Le Dantec, a prolific French popularizer at the beginning of this century, no formal difference between them can be identified. You will find scientific explanations in both, with extensive use of the specific terms which scientists use to talk about reality, and also frequent use of numbers which are always extremely precise as if they were the outcome of genuine scientific arguments. So the difference between these two kinds of texts will have to reside in some feature other than the specific use of language.

The fact is that, when you start reading science fiction in the form of a novel or of a short story, you are made to know, from indexical clues integrated within the text, that your reading is not oriented towards knowledge acquisition : there will be some kind of hero to identify with, mentions of dates will transport you to another time dimension, code-numbers will appear as part of common-sense knowledge, everyday life events will look different because of the apparatus used or some other trick such as : 'He took his breakfast pill and went out...', etc. Science fiction is made for entertainment and literary pleasure. Whatever the length of the narrative, you know from the text itself that it has a beginning and that, after a few hours, it will come to its happy -

\footnotetext{
${ }^{1}$ Pierre Lazslo, La vulgarisation scientifique, Paris, PUF, Coll. Que sais-je ?, 1992
} 
or unhappy - end. Your reading is managed to allow you to escape from everyday worries and problems.

Unlike science fiction, popularization of science texts will include formal clues which are especially designed to put you in a different mood. The reader's curiosity will be titillated by the difference between what he is supposed to know and what he is supposed not to know. The novelty of the content will make itself felt. The text will attempt to change your reading mood through an appeal to your curiosity, in a way which is frequently embedded in the formulation of the titles. They are constructed to present scientific knowledge in sharp contrast with your previous ideas on how things work :

'You thought that death was the end of everything. Nowadays, scientists are more and more convinced that death is just an illness !'

'If you thought that there was only one world in which humans could live, you were wrong ! Statistical evidence will demonstrate to you that life must exist somewhere else in the universe !' [366]

'You thought that... Now science wants you to believe that...'

In brief, whereas science fiction is using science in order to extrapolate to a possible world, the description of which will lead the reader to react by saying : 'Plausible, but not true!', popularization of science uses the same science in order to trigger an opposite reaction such as : 'Unlikely indeed, but true (since it is genuine science that says it) !'.

Reference to truth seems to be essential to give its proper dynamic to the popular presentations of science. And it is on the basis of such truth claims that this literary genre must be given its proper place and status within the whole of literature.

\section{Truth as content}

Now, if that is true (!), we are left with a serious problem. According to literary critics like Roland Barthes, Tzvetan Todorov or Julia Kristeva, ${ }^{2}$ truth cannot possibly be identified as the content of any piece of literature as such. Literature, they say, is concerned with likeliness or verisimilitude, not truth. Would that mean that popularization of science does not belong to literature ? Such a hypothesis would be in contradiction with the principle according to which any kind of written document is necessarily part of literature. On the other hand, the same hypothesis would fit the idea that the literary form of

2 This dimension of likeliness in literature was the main theme of the journal Communications, $\mathrm{N}^{\circ} 11$ (1968) Paris, with important contributions from Roland Barthes, Tzvetan Todorov and Julia Kristeva. 
popularization of science is not an essential component of it. We are sent back to the formula 'Many forms for one and the same content'.

As a consequence, do we have to abandon altogether the idea that popular science writing is literature ? If truth content is incompatible with literature as such, what shall we do with popularization of science texts? The answer that I gave in a previous work ${ }^{3}$ was to identify popularisation of science as the source of the myths of our modern 'scientific' and 'technological' societies. As such, it provides people with language resources (words, ideas, abstract entities, events, etc.). These are constantly renewed, in order to make sense out of the realities dealt with in everyday life and everyday contexts. Myths are special devices the purpose of which is precisely to involve truth contents within language, not by expressing them explicitly, but by making them felt and indicating their location in a space that is different from everyday settings. Besides that, their formal appearance (be it oral, textual, visual, or 'objectal' as in science museums) escapes criticism. They appear for something else than themselves, that is, for the truth content they refer to beyond their concrete form.

\section{Genuine autobiography}

That could be the end of the matter. But one cannot be satisfied with such a conclusion. Texts are still there, before our eyes. Is it really impossible to discover the implicit rules which would enable us to give them some kind of status within literature ? Isn't there another genre littéraire which, better that science fiction, would allow us to make a profitable comparison ? I believe such a genre does exist. Popularization of science might be compared to what Jean Starobinsky 4 has called 'genuine autobiography' through a critical analysis of Jean-Jacques Rousseau's Confessions. ${ }^{5}$

Starobinski's analysis starts with a remark on the question of the limits of the 'genuine autobiography'. All literary genres involve an implicit set of rules designed to [367] inform the reader about what they are about to read. These rules constitute a sort of grammar, or rather a 'meta-grammar', aiming at a temporal management of the interest of the reader between the beginning of the text and its end. The grammar is there in order to transform the spatial disposition of the text into a temporal process capable of fulfilling the expectations of the reader as determined by a reference to the genre. Now Starobinski, when looking for the limits of 'genuine autobiography', is rather embarrassed. 'Genuine autobiography' has no predetermined limits except the

\footnotetext{
${ }^{3}$ Baudouin Jurdant, Les problèmes théoriques de la vulgarisation scientifique, Doctoral thesis, Strasbourg, 1973 (unpublished).

4 Jean Starobinski, La relation critique, Paris, NRF, 1970, pp 83 sq

${ }^{5}$ Rousseau, Les Confessions, in Oeuvres I, Paris, NRF, La Pléïade, 1959.
} 
ones which are set by the author's birth - but that first limit is questionable since Tristram Shandy's autobiography - and by the author's death. This absence of limits is also a feature of popularization of science. It ranges from very brief notes published in daily newspapers to huge scientific encyclopaedias.

The fact that there are no predetermined limits for the management of the expectations of the readers makes it difficult indeed to find any rule as such in both 'genuine autobiography' and popularization of science. That is why Starobinski decided to appeal not to rules but to style in order to identify the literary classification of the genuine autobiography. Style is supposed to designate the singular or personal element in literary writing. It is more attuned to the efficiency of a law, something the author cannot wish away, than to simple rules.

\section{The redundancy of the personal pronoun}

How is this style to be defined ? First, one should mention the way Rousseau himself warns his readership about his own style. He says that, as he wants to tell the truth about his experiences and feelings in life, he will let the words of truth come out as spontaneously as possible. That means that he won't pretend to exercise any control on his own writing. His style will be what truth decides it to be. He wont care about coherence or consistency. He writes : 'It would be necessary, for what I have to say, to create a new language, a language just as new as my project is new.' 6 Yet, the text is, somehow, consistent. According to Starobinski, what gives it coherence and consistency is the most important element of Rousseau's style, that is, the redundancy of the ' $\mathrm{I}$ ' - the personal pronoun ' $\mathrm{I}$ ' - as not only labelling the writer within his own text and referring to himself as writing, but also as representing the main character of the narrative, Rousseau himself, portrayed in the most truthful way possible. One should remember Jean-Jacques Rousseau's solemn declaration at the beginning

\footnotetext{
${ }^{6}$ Rousseau, op.cit., p. 1153 : "Il faudrait, pour ce que j'ai à dire, inventer un langage aussi nouveau que mon projet : car quel ton, quel style prendre pour débrouiller ce chaos immense de sentiments si divers, si contradictoires, souvent si vils et quelques fois si sublimes dont je fus sans cesse agité ? (...) Je prends donc mon parti sur le style comme sur les choses. Je ne m'attacherai point à le rendre uniforme ; j'aurai toujours celui qui me viendra, j'en changerai selon mon humeur sans scrupules, je dirai chaque chose comme je la sens, comme je la vois, sans recherche, sans gêne, sans m'embarrasser de la bigarrure. [...] ...mon style inégal et naturel, tantôt rapide et tantôt diffus, tantôt sage et tantôt fou, tantôt grave et tantôt gai, fera lui-même partie de mon histoire."
} 
of the book, in which he says that he will tell nothing but the truth of himself and takes God as a warrant of his good faith.

Now, how could that apply to popularization of science and moreover what could be the consequences of such an analogy ? When comparing popularization of science texts over time in a field such as physics, for example, one notices very quickly that these texts are extremely redundant. A paper written in Science et Vie during the twenties, concerning life sciences or the origin of the universe will be very much like a paper written in the seventies in the same areas. But one should note that such a redundancy is only apparent. Popularization of science gives the impression of being extremely redundant and repetitive. I think that this impression is caused by the combination of two components : first, the use of the ordinary language within which science is incorporated, and second, the recurrence of technical words. These words are not the same and they may refer to completely different things in reality, but their occurrence in the text obeys the apparently identical logic of presentation. [368]

This redundancy is quite mysterious since popularization of science pieces are supposed to carry not only a lot of information but also information which is new with regards to the expectations of the lay reader. Strangely enough, the constant use of scientific terms and numbers seems to obey more a stylistic requirement than a didactic rule. Numbers are of special interest here. They usually appear in texts without any indication of their range of validity. No clues are given to the reader about how they were found, measured or calculated. Their relevance is usually trapped in semantic opposition such as the one between the "biggest" and the "tiniest". Their literal exactness - which is what makes them really scientific! - cannot be assessed by the reader. They have to be taken on trust. In different accounts of brain studies, one can be told that the neuronal population amounts to 1, 10 or 100 billions of cells. Actually, the precision which is offered here does not really matter ${ }^{7}$. As Bachelard put it : 'A precision given about a result, when it goes beyond the precision of the experimental data, is most exactly the determination of nothingness.' 8

\section{Self-referential jargon}

\footnotetext{
7 Bachelard, Gaston, La formation de l'esprit scientifique, Paris, Vrin, 1966 (p.214) : "Au XVIIIe siècle, l'excès tout gratuit dans la précision est la règle. Nous n'en donnerons que quelques cas pour fixer les idées. Par exemple,Buffon arriva "à ces conclusions qu'il y avait 74.832 ans que la Terre avait été détachée du soleil par le choc d'une comète; et que dans 93.291 années, elle serait tellement refroidie que la vie n'y serait plus possible." Cette prédiction ultra-précise est d'autant plus frappante que les lois physiques qui lui servent de base sont plus vagues et plus particulières."

8 Ibidem, p. 214 : "Une précision sur un résultat, quand elle dépasse la précision sur les données expérimentales, est très exactement la détermination du néant." (Bachelard's italics).
} 
The use of bits and pieces of scientific jargon is susceptible to the same kind of diagnosis. People could be told anything, provided that a new word has been coined to encapsulate the novelty. Scientific terms are useful tools for giving truth contents to the narratives which are inspired by science. What is important in their use is their literal precision. The scientific term is there to guarantee the origin of the text, its credibility as a genuine outcome of scientific activity. It means 'science' and refers globally to the origin of the writing process, just as, in the autobiography, the personal pronoun ' $\mathrm{I}$ ' refers to the actual writing of someone about themselves. In popularization texts, scientific terms acquire a sort of self-referential value since the lay reader has no access to the 'realities' they refer to for the specialist. Of course, they do refer to such 'realities'. In that sense, they refer just as, in 'genuine autobiographies', the ' $\mathrm{I}$ ' refers, with all its clues of indexicality, to 'real' events and feelings of the past as they were supposed to heve been lived or felt by the writer at the time. In other words, the recurrent use of technical bits of the specialist's jargon makes science appear as one single and living entity. Its unity is an outcome of its own autobiography, as expressed by journalists and elderly scientists remembering the good old days of their scientific career.

This feature has been noticed by Marcel La Follette when she says that 'scientists and journalists alike [...] often anthropomorphized the concept, making science into a living, growing thing that could 'do' things, could 'act', could even 'assert'. In truth, of course, a writer could only describe what individuals did, how they acted, what they asserted ; but underlying the factual description was always the implication that there was some powerful entity called science - with a mysterious and unstoppable life of its own. ${ }^{9}$

\section{The 'reality effect'}

Such an image of science helps public accounts of scientific knowledge to give science its unity and to involve, in the reported events which make up its present life, a 'reality effect' of the same sort as the one Rousseau wants to convey using to the stylistic clues of authenticity that he created in the autobiographical account of [369] his own life. These stylistic clues include the permanence of the ' $\mathrm{I}$ ' through various tones and expressions as if they were dictated by truth itself.

In the popularization of science, this 'reality effect' is induced by the literal permanence of technical words through the multiplicity of the perspectives that popular presentations of science involve as a whole. For reality to be one and the same for all, it has to be made accessible from different points of view. It has

\footnotetext{
${ }^{9}$ Marcel C La Follette, Making science our own. Public images of science 1910-1955, London, The University of Chicago Press, 1990.
} 
to be made 'gone roundable', contournable, visible from different angles. When Fontenelle wanted, in his Preface to the Histoire des Oracles, to vindicate the conversational style that he had used to present the pure science of his sourceauthor, he said that he had been puzzled by the choice he had to make since 'there is one middle, and even several of them!' This awareness of the diversity of levels he could address echoes the diversity of tones and metaphors that the expression of the actual events of his life was imposing on Rousseau's style.

By multiplying the angles from which scientific results can be made knowable, popularisers convey the feeling that what they talk about is indeed 'gone roundable'. Reality has this particular feature of being three-dimensional which makes it possible to circle it and, through that circling movement, to see it from various angles without inducing changes in its definition. It could also be for this reason that the popularization of science is not really part of literature : it does not involve any rule which could turn it into a genre littéraire like any other. The written form is one of the possibilities that it uses to convey science's new definitions of reality. But this form is not, and should not appear, essential. It must give the reader the impression that the reality involved in its presentation does not depend on the literary form as such. (This points to one of the main reasons why Buffon's scientific work was neglected by the rising class of professionnal scientists in the XIXth centurty : his works were regarded as too literary for his claims to scientific authenticity tobe plausible.) The written form has to convey the idea that such realities are not just readable, but that they are also and moreover visible to our eyes, tangible to our hands, audible to our ears, and so on, just as reality appears to be in everyday life. The only way to convey such an idea in writing, involves a sort of denial of the relevance of what could be considered as literary in its own written form. In brief, if popularization of science is so difficult to consider as a part of literature, it is because it must deny belonging to it. Without such a denial, its truth-claims would not be plausible and its reference to realities would become empty.

\section{Whom is popularization of science for?}

This analysis confirms the idea that popularization of science is more concerned with the construction of a mythical background for lay people to provide meanings to the world around them, than with a proper transmission of scientific knowledge that could challenge experts' monopoly on the definition of reality. But that end result should not be considered as what it deliberately aims to be. It is an indirect outcome of the textual properties of its literary form. So we might still wonder about the actual purpose of popular presentations of science.

In order to answer that question, it might be useful to have a second look at that 'reality effect' produced by scientific popularization. One must agree with the fact that such an effect does not help laypeople in their practical dealings 
with reality. It does [370] not increase the efficiency of their control over it. So the question might be formulated differently : if not for lay people, for whom is this 'reality effect' produced?

We have no choice : this 'reality effect' cannot but be produced for scientists themselves. In other words, popularization of science seems to have an epistemological role to play within science itself. Thanks to it and thanks to the diversity of its forms, scientific representations will be able to lose their representational aspects. They will become anchored in the 'real world of nature' as we all experience it through ordinary language and as scientists are made to believe it to be when working in their laboratory. The significance of such a role is that not only popularization of science be regarded as part of science itself but also that it is a necessary ingredient if scientists are to get rid of their suspicion that they themselves are dreaming as Descartes might have feared and as people like Fleishmann and Pons with cold fusion ${ }^{10}$, or Blondlot with N-rays, seem to have experienced in their own fields of research.

If such a conclusion is valid, then popularization of science would be the symptom of a desappropriation mechanism whereby scientists are able to relate their knowledge to nature. The 'reality effect' is essential for them and it starts from the very beginning of their laboratory work when they discuss the significance of the results of their deciphering activity. It is through that effect that they might succeed in achieving passivity, in the sense meant by Rudolf Fleck in his constructivist approach of science. ${ }^{11}$

\section{The reflexivity of science}

The final point of this comparison between popularisation of science and 'genuine autobiographies' seems to me to be concerned with reflexivity. Through its popular presentation, science is mainly concerned with itself rather than with some kind of educational purpose, just as Rousseau is mainly concerned with himself in his Confessions. How was he to achieve a reconciliation between his hic and nunc writing ' $\mathrm{I}$ ' and his written and experienced ' $\mathrm{I}$ ' of the past? How was he going to enable his past ' $\mathrm{I}$ ' to catch up with his writing ' $\mathrm{I}$ ' in order to make sense of his own life? How could his split ' $\mathrm{I}$ ' escape an increasing literary gap between himself and himself ?

The solution to that problem cannot be found easily. But I think that if reflexivity is problematic in autobiographical texts, it is because it has something to do with the very act of writing. In spoken forms of language,

$10 \mathrm{Cf}$. the contribution of Bruce Lewenstein in this special issue of Public Understanding of Science

${ }^{11}$ Fleck, Rudolf, Genesis and Development of a Scientific Fact, Chicago, University of Chicago, 1979 
reflexivity is spontaneously achieved through the actual use of shifters, that is, words which have contextually dependant meanings. It is through the use of the speaking/spoken ' $\mathrm{I}$ ' that reflexivity plays a role in the configuration of consciousness. Not that the speaking/spoken ' $\mathrm{I}$ ' could pretend to be less ambivalent than the written/writing ' $\mathrm{I}$ '. But, concerning the latter, the split is permanently translated into a time gap whereas, the speaking/spoken ' $\mathrm{I}$ ' achieves reflexivity through his linguistic interactions with other people in concrete and local situations.

If we now turn to popularization of science for an acceptable transposition, one must identify the two sides of that 'split science' which tries to escape its own ambivalence. The track that I think would be worth exploring is based on the hypothesis that the scientist is first of all a reader and that science involves two kinds of readability : first, there is the readability of the world as referred to by Galileo in many famous passages of his works, and out of which scientists get their unreadable [371] writings ; and second, there is the 'verbalised readability' of the words of science when it enters the realm of ordinary language, that is, when confronted with popular audiences. Here the reading activity gets a social/quasi-oral dimension without which reflexivity can hardly be achieved. Popularization of science articles and books are quasi-oral because of their selfdenial of being part of literature. They are read to be talked about in all kinds of different places : from the XVIIIth century salons, to the public debates of today which are the real social settings where they can acquire a genuinely didactic effect. ${ }^{12}$ In these situations, it is not so much science that people want to comment upon as reality itself as it constitutes daily life. That is also why the 'reality effect' I have tried to identify in popularization of science is so intimately connected with the self-referential function that it fulfils for science itself.

I think that modern science could not survive if it restricted itself either to the first or to the second kind of readability. The second kind is just as necessary as indeed, just as inescapable as the first if science is to survive in its modern, galilean style. And, as it has been beautifully demonstrated by Daniel Jacobi ${ }^{13}$ for instance, that second kind of readability - what Jacobi has called science's figurability - is already at stake within the scientific laboratory during the ongoing process in which scientists indulge of talking to each other while working at the bench ${ }^{14}$, tuning a particle detector, meeting in seminar rooms and symposia, commenting on scientific news over the phone to journalists or

${ }^{12} \mathrm{Cf}$. the contribution of Camille Limoges in this special issue of Public Understanding of Science.

13 Jacobi, Daniel, Textes et images de la vulgarisation scientifique, Berne, Peter Lang, 1987.

${ }^{14}$ Cf Lynch, Michael, Art and Artifact in Laboratory Science, A Study of Shop Work and Shop Talk in a Research Laboratory, London, Routledge and Kegan Paul, 1985. 
politicians or arguing with their spouse about the urge to go back to the lab after dinner. [372] 